\title{
Reposition Taxpayer Awareness Through Zakat in Indonesia
}

\author{
Elis Teti Rusmiati ${ }^{1}$, Alan Hidayat ${ }^{2}$ \\ \{elistetirusmiati@dsn.moestopo.ac.id ${ }^{1}$, alan.hidayat@dsn.moestopo.ac.id² \\ ${ }^{1,2}$ Faculty of Social and Political Science of Universitas Prof. Dr. Moestopo, St. Hang Lekir \\ I/8 Jakarta, Indonesia
}

\begin{abstract}
Tax obligations in Islam are known with the concept of zakat as source of state income since the beginning of the Islamic government. In Indonesia, Muslim citizens have two obligations: zakat as a form of obedience to religion, and taxes as a form of obedience to the state. There is a problem because of twice payments from income. In addition, two types of obligations also give the impression about dichotomy in Indonesia by separating religious affairs from state affairs. This paper aims to repositioning the awareness of taxpayers through zakat. The method in this paper is literature study. The results of the study found that awareness is growing significantly in zakat, it is more different than the tax for the state. In religious societies especially in Indonesia, the desire to implement religious rules is stronger than state rules. Indonesia as Muslim majority country is very appropriate to combine the elements of charity as bait encouragement to the taxpayer. It can conclude the realignment or put back taxpayer awareness through zakat as an effective way to carried out. It can be developed by repositioning tax through zakat.
\end{abstract}

Keywords: tax, zakat, obligation, reposition, awareness.

\section{Introduction}

Zakat in Islam is an individual obligation which has been defined in the Al Quran. Zakat is one of the sources of state income since the beginning of the Islamic government. Khalifah (Islamic leader) who was known for carrying out reforms in the management of zakat was Umar bin Abdul Azis (717-720 AD). In his time, system and management of Zakat was controlled very professionally. Type of property and wealth substance to obligatory zakat is increasingly diverse.

In Indonesia, tax is the source of income for the management of the country. However, the level of taxpayer submission is still low even though Indonesia's development sources come from the State Expenditures Budget. It is $76 \%$ supported by tax revenues.

The issue of tax revenue has returned to be hot issues now days because it involves the independence of the nation in carrying out development. Government debt for development has been highlighted by unsuccessful of the tax revenue target in 2017. The strong desire of the government to accelerate infrastructure development in the framework of overcoming poverty, unemployment and inequality among fiscal constraints is a challenge for the Directorate General of Taxes. In the peak reporting of Annual Tax Returns for Personal PPh on March 31, 2018, the submission of reports has not reached the specified target of $64.5 \%$ for quarter 1. [1] 
Zakat and tax are two different things. Muslim citizens in Indonesia have two obligations: zakat as a form of obedience to religion, and taxes as a form of obedience to the state. There is a problem because of twice of the payments from income. In addition, two types of obligations also give the impression about dichotomy in Indonesia by separating religious affairs from state affairs.

The government has carried out several efforts to boost the level of taxpayer compliance, among citizen through regulation No. 23 of 2011 about Management of Zakat. In regulation no $22-23$, it is explained about zakat rate. It is deducted from taxable income. Evidence of zakat deposit can be used as a deduction from taxable income. This policy also has an impact on the true of relief for Indonesian Muslims because they are not exposed to double spending.

This paper aims to reposition or reorientation the awareness of taxpayers through zakat. In religious communities especially in Indonesia, the desire to implement religious rules is stronger than state regulations especially zakat obligations because there are also no sanctions for violators. The obligation to pay zakat for aMuslim is absolute because it is part of carrying out the Pillars of Islam. In other words, zakat is an individually binding obligation. In the context of Indonesia, the majority of Indonesia's population is Muslim. It is very appropriate to incorporate the element of zakat as bait for encouraging taxpayers.

\section{Theoretical framework}

The importance of zakat for Muslims is written in the Al Qur'an such as in Al-Baqarah (2): 110: "You must pray and pay zakat. And whatever good things you try for yourself, surely you will get the reward by Allah's side. God sees what you do." [2]

Zakat is supplied assets by Muslims to society. They must have the right to receive zakat such as the poor. It is based on specification by shariah (Islamic regulation). Zakat is pillars of Islam. It is one of the most important elements in upholding Islamic law. Therefore the law of zakat is obligatory for every Muslim who has fulfilled certain conditions. Zakat is a form of worship such as prayer, fasting, and others. It has been arranged in detail based on the $\mathrm{Al}$ Qur'an and Sunnah Rosul.

There are several types of zakat with different conditions and calculation methods. Zakat from daily earning (zakat from profession) is one type of zakat. It must be paid from income. If he has generated income reaching the nishab (the minimum standard of property that must be for zakat), a muslim will be obliged to issue this. Based on the fatwa (provision) of the Indonesian Ulama Council (MUI), the income is equivalent to 85 grams of gold in one year. This zakat can be paid at a rate of 2,5\%. [3]. If the price of gold is IDR $600.000 / \mathrm{gram}$, it will be in 85 grams x IDR 600.000: 12 months = IDR 4.250.000. Thus, if the income in one month reaches IDR 4.250 .000 or exceeds it, it will be obligatory to pay zakat income $2.5 \%$.

Tax is a source of state revenue. It is essential in sustaining domestic financing for development. Tax is an obligation on someone who has fulfilled the category as a taxpayer. In Indonesia, personal taxpayers who are liable to pay taxes are those who earn a minimum of or more than IDR 54 million per year or IDR 4.5 million per month. This regulation is imposed on taxation in accordance with Minister of Finance Regulation 101/PMK.010/2016 about Non-Taxable Income in 2016. Therefore, if someone have a net income under IDR 4.5 million per month, it is not mandatory to pay taxes. On the other hand, if the net income for a year is equal to or above IDR 4.5 million per month, they must pay income tax and report the Annual Tax Return. [4] 


\section{Method}

The method is library research. In literature study activities carried out theoretically, references and other scientific literature relating to culture, values and norms in the social situation. [5]. In addition, this research field research on: compulsory zakat and tax, receiver (mustahik) charity and the institutions of zakat such as Badan Amil Zakat Nasional (BAZNAS) or Lembaga Amil Zakat (LAZ) and several mosques.

\section{Results and Discussion}

Tax and zakat discussions are always remarkable topic, especially related to the integration both of them. In this paper, the integration effort is carried out in repositioning tax obligations by zakat. This reposition is intended to reduce the tax burden on Muslims in Indonesia because they are not only subject to paying taxes but also are obliged to pay zakat.

The essence of tax and zakat is in the same side as the solutions to reduce poverty and economic inequality. Is it an obligation to pay taxes after paying zakat? Likewise, is it an obligation to pay zakat after paying tax? The answer is yes. Zakat and tax have different dimensions. Zakat is an absolute religious obligation, whereas tax is an obligation of the state. The obedience to the state is also ordered in religious wisdoms. Legally both must be implemented.

Despite having the same essence, zakat and taxes cannot be reduced to one. Religion regulation in zakat cannot replace the obligation of the state (taxes). It does not mean someone free to pay zakat after paying tax. In other words, there are two obligations for Muslims in Indonesia: zakat and taxes.

It is double obligation. There is twice the expenditure from income by Muslims in Indonesia. On the other hand, the obligation to pay zakat is differentiated from paying the tax. It increases the impression that religious affairs are completely separate from state affairs.

There are several reasons that are difficult to encounter on tax repositioning of zakat. Daud Ali declared several aspects to show the difference between zakat and tax. 1) zakat is a religious obligation established by God, and the tax is determined by government; 2) zakat is responsibility for Muslim while taxes are not only for Muslims but Indonesian citizens regardless of religion; 3) zakat recipients are already certain groups, while taxes are for residents in a country; 4) if someone do not pay zakat, the sanctions will be sins; while if someone do not pay tax, the sanctions will be fines; 5) Zakat cannot be abolished because it is a pillar of Islam, while taxes may be replaced or abolished depending on the consideration of the government and the state of a country. [6]

It reflects the position of zakat. It is more strongly binding on a Muslim than tax. Reposition concept in this paper is mandatory zakat awareness as a trigger to pay taxes. The obligatory of zakat is more important than the taxpayer on the perspective of religious belief.

Basically, zakat as a form of obedience to religion (God) is a higher and absolute position, whereas tax is a state obligation. In terms of compliance, a higher position will take precedence. It cannot be replaced by the position below it. The type of obedience to religion (zakat) will be more important than obedience to paying taxes. Thus, the awareness of paying zakat for a Muslim will take precedence or priority. In the condition of Indonesia as the majority of Muslim, this method is considered significant.

It is the essence of regulation no 23 of 2011 about Management of Zakat in repositioning. Zakat can be a deduction from taxable income. If someone pays his or her zakat, the amount of tax debt becomes reduced. 
This condition is very progressive because zakat as a deduction of tax. It will reduce the double burden of zakat and tax payments by the public. It also will provide a stimulus to the Muslim citizen to be honest and upright in doing his own tax. The true repositioning of taxes by zakat will naturally increase tax revenues by the government. Zakat will give positive and significant impact in affecting government tax revenue. The awareness of zakat will significantly affect taxpayer revenue.

Zakat is one of the Five Pillars of Islam (dimensionless worship). It is also a social dimension (muamalah) which has noble objectives such as:

1. It will keep our self from being greedy, stingy, and ambitious. It is written in the $\mathrm{Al}$ Qur'an on At-Taubah: 103: "Take zakat from some of their material, you can cleanse and purify their heart"

2. The basis of zakat is empathy and a sense of mutual help.

3. Paying zakat means thanking God for fortune. Al Qur'an in Ibrahim: 7: "if you are grateful, we will add (favor) for you"

4. Zakat can also maintain a balance between the rich and the poor. In the Al Qur'an surat Al-Hasyr: 7): "So that the treasure should not be circulated among the rich only among you."

This belief encourages even binding Muslims to hasten and prioritize the obligation of zakat. Thus, the essence of individual awareness to carry out the obligation of zakat is very strong. So if this potential is developed and synergized with tax obligations, it will be reasonable. Basically, the right solution in awareness of taxpayers is a mandatory awareness of zakat.

The legal basis for income tax deduction of zakat is regulation No. 23 of 2011 on Zakat Management. In regulation no 22, it is explained that the zakat paid by muzaki (someone who pay zakat) to BAZNAS (Zakat National Agency) or LAZ (Zakat Institution) is deducted from taxable income. [7]

The concept is zakat can reduce the tax. It means that the objects of tax reduce and it does not mean the nominal of the tax. The calculation is the zakat payment to the institution or zakat agency which is officially appointed by the Government, with the income of the taxpayer for a year.

In order to claim tax deduction for the payment of zakat, it must take the following steps:

1. Attach a photocopy of evidence of payment at the Annual Income Tax for the Year of Tax to reduce zakat or compulsory religious contributions.

2. The evidence is payment through directly, bank account transfer or payment through an Automated Teller Machine (ATM).

3. Evidence of paying zakat or other religious contributions, at least contains some basic information such as: Full name of Taxpayer and Taxpayer Identification Number (NPWP), amount of payment, date of payment, zakat agency identity or zakat institution or religious institution formed and authorized by the government, signature of the official zakat agency or other religious institution in evidence of payment (directly payment), validation of the bank officer on evidence of payment (bank account transfers).

If someone fulfill these requirements, the zakat or religious donation will be propose as a tax deduction on their annual tax return. On the other hand, if it does not fulfill the requirements, it cannot be the payment of zakat or religious contributions as a tax deduction.

It is certainly not an easy step to repositioning the tax by zakat. Government regulation has been occurred for long enough. The problem is on the information itself. Why does not society realize that income for zakat payments help taxpayers to reduce personal tax burdens? 
Tax management is carried out by the directorate general of the ministry of finance, while zakat is managed by LAZ or BAZNAS under the ministry of religion. We need better coordination and cooperation. So, the community is facilitated with this capacity. There are still not many people familiar with zakat as a tax deduction. It needs more maximal socialization to society about government policy about zakat as a tax deduction.

Other issues in implementing the regulation No. 23 of 2011 on the Management of Zakat are majority of society do not have official evidence of BAZ/BAZNAS as government agency. Practically, most of people pay zakat payments in mosques or even given directly to mustahik (the recipient of the zakat), it does not have evidence of deposit as required by the law. The problem in the implementation of the Law on Management of Zakat is the tax calculation becomes taxable, the risk of tax returns is checked.[8]. On the other hand, the value of zakat does not significantly reduce taxes. It is the foundation of people to reluctant to attach evidence of payment of zakat on their annual tax return.

However, effectiveness and efficiency in the process of zakat payment as a tax deduction is very necessary to maximize the impact on society. If the Government creates a beneficial atmosphere in giving the zakat as a tax deduction, the muzaki will more enthusiastic to pay zakat. So, the number of muzaki will increase. It will increase the number of taxpayers. Indonesian society is statistically more engaged in the informal sector. Worker in the informal sector, are not used to paying taxes, but they still regularly pay zakat.

If a conducive atmosphere is created, zakat payments will also simultaneously record data as a taxpayer because the process of paying taxes is carried out simultaneously by paying zakat. On the other hand, some studies conclude that the Muslim community is more satisfied to pay zakat than taxes. This condition has the potential to the government. Zakat as a tax deduction with professional and transparent management is more efficient.

Furthermore, it can be considered to reposition the government-controlled zakat intact through the ministry of finance, as well as taxes. The opportunity for zakat as a tax deduction will be more prospective. It could even be an alternative fiscal policy in Indonesia. The power of the state increases because there is zakat in addition to taxes. The regulation of Zakat by government is written in the Al Qur'an. The state is required to be actively involved in the management of zakat. In At-Taubah:103, it is explained about the urgency of zakat to be taken and managed by the officers (amil) of zakat. [9]

\section{Conclusion}

Zakat and tax cannot be reduced to one but there is a legal way to reduce both of these payments by calculating zakat payments which can be a deduction from the tax. Repositioning awareness of taxpayers through mandatory zakat implies optimizing zakat as a tax deduction. In religious societies, especially in Indonesia, the urge to implement religious rules is stronger over state rules. The majority of Indonesia's population is Muslim, it is very appropriate to incorporate the element of zakat as bait for encouraging taxpayers. It is necessary to improve political motivation of governments to maximize socialization and create an atmosphere conducive for the repositioning of zakat as a tax deduction.

\section{References}

[1]. Bayu Tjahyono, Mochammad: Sudah Cukupkah Kepatuhan Pajak Kita? on Friday, April, 202018 http://www.pajak.go.id/article/sudah-cukupkah-kepatuhan-pajak-kita

[2]. Al-Quran Translation. Departemen Agama RI. Bandung: CV Darus Sunnah (2015).

[3]. Fatwa of Majelis Ulama Indonesia No 3 in 2003 about income zakat. 
[4]. Regulation No 36 in 2008 about Income Tax (PPh)

[5]. Sugiyono: Understanding Qualitative Research, Memahami Penelitian Kualitatif. Bandung: Alfabeta (2012)

[6]. Daud Ali, Mohammad: Islamic Economic System: Zakat and Waqaf, Sistem Ekonomi Islam: Zakat dan Wakaf, Jakarta: UI Press (1988)

[7]. There are many provisions that have been issued about it, such as Presidential regulation Number 8 of 2001 about the Establishment Baznas, regulation Number 23 of 2011 about Management of Zakat, and Government Regulation Number 14 of 2014 about Implementation of regulation Number 23 of 2011 about Management of Zakat 